\title{
THE IMPORTANCE OF CALCULATING GREEN GDP IN ECONOMIC GROWTH OF A COUNTRY - CASE STUDY ALBANIA
}

\author{
Flora Merko ${ }^{1}$, Esmeraldo Xhakolli ${ }^{1}$, Henrieta Themelko ${ }^{2}$, Florjon Merko ${ }^{3}$ \\ ${ }^{1}$ Aleksander Moisiu University, Department of Economics, Durres, Albania; \\ ${ }^{2}$ Agriculture University of Tirana, Department of Economy and Agriculture Policy, Tirana, Albania; \\ ${ }^{1}$ Aleksander Moisiu University, Department of Marketing, Durres, Albania; \\ *Corresponding author: Flora Merko, e-mail: floramerko@ yahoo.it;
}

Received March 2019; Accepted April 2019; Published July 2019;

DOI: https://doi.org/10.31407/ijees9308

\begin{abstract}
Gross Domestic Product (GDP) or Gross National Product (GNP), are commonly used to determine the economic performance of a whole country or region, to make international comparisons and to measure the produced output but they ignore the ingredients needed to generate such output like water and air. So, there is a general consensus that these indicators, (especially) according to the concepts of sustainable development and green growth, appear to be poor measurements. Environmental sustainability of economic growth has come to be recognized as one of the most important pillars of sustainable growth and development. Green GDP is an Index, an alternative indicator of economic growth that incorporates environmental consequences of that growth by including the depletion of natural resources and degradation of the environment, so it takes into consideration the environmental impacts on the productivity of the country. Taking in consideration that the main purposes of Green GDP accounting are used to provide a more correct measure of welfare and to examine the sustainability of the economy, we used this indicator to give our opinion for the importance of calculating Green GDP in the economic growth of Albania. We use the general scheme of calculation where the first deduction in GDP presents the costs of $\mathrm{CO}_{2}$ pollution (as $\mathrm{CO}_{2}$ emissions times carbon market price), second the opportunity costs of one tone of waste that could be used in the production of electrical energy), and a third is the adjusted savings of natural resource depletion as a percentage of the gross national income per country. Hence, we try to build an alternative Green GDP indicator that can give a clearer perspective on the consequences of economic progress by offering a new approach in quantifying the cost of ecological and environmental degradation in Albania. Not only will it evaluate the real costs of environmental damage, but it will also process some opportunity costs in Albania Case.
\end{abstract}

Keywords: Green GDP, Economic Growth, Environmental Damage, Sustainable Development. 